\title{
Pengaruh Pendekatan Saintifik dalam Strategi Pembelajaran Thinking Aloud Pair Problem Solving (TAPPS) untuk Meningkatkan Kemampuan Pemecahan Masalah Fisika Siswa Kelas X SMA Negeri 08 Palu
}

\author{
Irmayanti, I Wayan Darmadi, dan Supriyatman \\ Irmayantiibrahim3@gmail.com \\ Program Studi Pendidikan Fisika FKIP Universitas Tadulako \\ Jl. Soekarno Hatta Km. 9 Kampus Bumi Tadulako Tondo Palu - Sulawesi Tengah
}

\begin{abstract}
Abstrak - Penelitian ini dilatarbelakangi oleh rendahnya kemampuan pemecahan masalah fisika siswa SMA. Tujuan penelitian ini adalah untuk mengetahui pengaruh pendekatan saintifik menggunakan strategi pembelajaran TAPPS untuk meningkatkan kemampuan pemecahan masalah fisika siswa. Metode penelitian yaitu kuasi eksperimen dengan desain "the equivalen, pretest-postest design". Populasi penelitian ini adalah seluruh siswa kelas X SMA Negeri 8 Palu tahun ajaran 2017/2018. Pemilihan sampel adalah siswa kelas X IPA 1 dan X IPA 2. Data penelitian diperoleh melalui tes kemampuan pemecahan masalah siswa dan lembar observasi. Berdasarkan analisis data, diperoleh sampel yang terdistribusi normal dan homogen. Dilakukan pengujian hipotesis dengan taraf signifikan $\alpha=0,05$ dan diperoleh hasil Tes akhir, $t_{\text {hitung }}>t_{\text {tabel }}$ atau 3,15 $>1,68$ hal ini berarti $\mathrm{H}_{0}$ ditolak dan $\mathrm{H}_{1}$ diterima, jadi hasil penelitian menunjukkan bahwa terdapat pengaruh pembelajaran dengan pendekatan saintifik menggunakan strategi Thinking Aloud Pair Problem Solving (TAPPS) untuk meningkatkan kemampuan pemecahan masalah fisika siswa.
\end{abstract}

Kata Kunci: pendekatan saintifik, strategi thinking aloud pair problem solving, kemampuan pemecahan masalah fisika.

\section{PENDAHULUAN}

Pada pembelajaran fisika, kemampuan siswa dalam menyelesaikan masalah masih tergolong rendah. Siswa lebih sering mengerjakan soalsoal fisika yang diberikan oleh guru, langsung menggunakan persamaan matematis tanpa melakukan analisis, menebak rumus yang digunakan dan menghafal contoh soal yang telah dikerjakan untuk mengerjakan soal-soal lain [1]. Kurangnya kemampuan pemecahan masalah meliputi pemahaman yang lemah tentang prinsip dan aturan fisika, kekurangan dalam memahami soal, dan tidak cukup motivasi dari siswa [2]. Untuk memperbaiki pendidikan di Indonesia, pemerintah melakukan upaya dengan menerapkan kurikulum 2013. Kehadiran kurikulum 2013 tidak lepas dari kurikulum sebelumnya, yakni KTSP tahun 2006. Kurikulum 2013 sebagai hasil dari penjabaran Permendikbud No. 65 Tahun 2013 [3], tentang Standar Proses Pendidikan Dasar dan Menengah yang mengisyaratkan tentang perlunya proses pembelajaran yang dipandu dengan kaidahkaidah pendekatan saintifik atau ilmiah. Pendekatan saintifik atau biasa disebut sebagai pendekatan ilmiah, merupakan konsep dasar yang menginspirasi atau melatar belakangi perumusan metode mengajar dengan menerapkan karakteristik yang ilmiah. Pendekatan pembelajaran ilmiah (scientific teaching) merupakan bagian dari pendekatan pedagogis pada pelaksanaan pembelajaran dalam kelas yang melandasai penerapan metode ilmiah [4]. Penerapan pendekatan saintifik dalam pembelajaran melibatkan keterampilan proses seperti mengamati, mengklasifikasi, mengukur, meramalkan, menjelaskan, dan menyimpulkan. Dalam melaksanakan proses tersebut, bantuan guru diperlukan. Akan tetapi bantuan guru tersebut harus semakin berkurang dengan semakin bertambah dewasanya siswa atau semakin tingginya kelas siswa.

Adapun alternatif strategi pembelajaran yang sesuai dengan pendekatan saintifik pada kurikulum 2013 adalah strategi pembelajaran Thinking Aloud Pair Problem Solving (TAPPS). Penerapan strategi pembelajaran TAPPS ini dapat memudahkan siswa untuk menyelesaikan permasalahan dalam pembelajaran fisika. Strategi TAPPS mengutamakan kerja sama antar pasangan dalam memecahkan suatu permasalahan. Adpun strategi pemecahan masalah yang digunakan dalam penelitian yaitu: visualisasi masalah, mendeksripsikan masalah dalam istilah-istilah fisika, merencanakan solusi, menyelesaikan rencana solusi, mengecek dan menguji solusi [5].

Karena paparan diatas, maka dapat disimpulkan bahwa strategi pembelajaran TAPPS mampu meningkatkan kemampuan 
p-ISSN 2338-3240, e-ISSN 2580-5924

pemecahan masalah siswa. Oleh karena itu, penelitian ini akan dilakukan dengan menggunakan pendekatan saintifik dalam strategi pembelajaran Thinking Aloud Pair Problem Solving (TAPPS) untuk meningkatkan kemampuan pemecahan masalah fisika siswa.

\section{METODE PENELITIAN}

Jenis penelitian yang digunakan pada penelitian ini yaitu penelitian eksperimen kuasi. Penelitian eksperimen kuasi merupakan metode penelitian yang digunakan untuk mencari pengaruh perlakuan tertentu terhadap yang lain dalam kondisi yang terkendali [6]. Desain dalam penelitian ini menggunakan desain dengan rancangan Tes awal-Tes akhir yang Ekuivalen (the equivalen, Pretest-Postest Design).

Populasi dalam penelitian ini adalah siswa kelas X IPA SMA Negeri 8 Palu Tahun Ajaran 2017/2018, dan yang menjadi sampel penelitian adalah siswa kelas X Ipa 2 sebagai kelas eksperimen, dan X Ipa 1 sebagai kelas kontrol. Dengan teknik pengambilan menggunakan purposive sampling.

Instrumen yang digunakan dalam penelitian ini adalah tes kemampuan pemecahan masalah fisika siswa. Instrumen tes kemampuan pemecahan masalah fisika dikembangkan melalui validasi. Tes yang diberikan berbentuk essay sebanyak 5 soal tes kemampuan pemecahan masalah dengan skor maksimal tiap soal adalah 20. Materi yang diujikan dalam tes yaitu suhu dan kalor.

Data yang diambil pada penelitian ini berasal dari 19 siswa pada tiap sampel. Metode pengumpulan data pada penelitian ini, menggunakan tes kemampuan pemecahan masalah dan observasi. Lembar observasi terdiri dari lembar observasi siswa dan guru yang diisi oleh observer ditiap pertemuannya.

Teknik analisis data yang digunakan adalah uji statistik parametrik (uji t-1 pihak). Pengujian hipotesis dilakukan di bawah taraf signifikansi $a=0,05$. Sebelum dilakukan pengujian hipotesis terlebih dahulu diuji persyaratan menggunakan kenormalan sebaran data dengan menggunakan persamaan Chi-kuadrat dan homogenitas varians.

Uji normalitas bertujuan untuk melihat apakah data dari subjek penelitian berdistribusi normal atau tidak. Selanjutnya, dilakukan uji homogenitas varians dengan menggunakan uji-F untuk mengetahui apakah tes kemampuan pemecahan masalah fisika memiliki kehomogenan varians pada kedua kelas sampel. Jika sebaran data berdistribusi normal dan homogen, maka data yang diperoleh dianalisis dengan menggunakan uji statistik parametrik (Uji-t 1 pihak).

Untuk mengetahui peningkatan perubahan konsep yang diperoleh pada kelas eksperimen dan kelas kontrol dihitung berdasarkan skor $\mathrm{N}$ gain.

\section{HASIL DAN PEMBAHASAN}

\section{A. Hasil Penelitian}

Penelitian ini bertujuan untuk mengetahui ada tidaknya pengaruh pendekatan saintifik menggunakan strategi pembelajaran Thinking Aloud Pair Problem Solving (TAPPS) untuk meningkatkan kemampuan pemecahan masalah fisika siswa yang dihitung dengan menggunakan persamaan $\mathrm{N}$-Gain. Kemudian Data disajikan dalam diagram berikut.

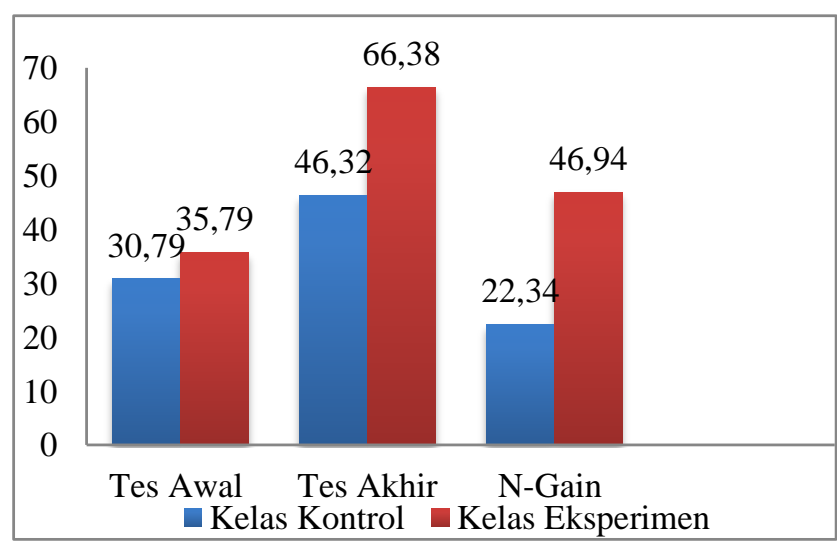

Gbr. 1 Diagram perbandingan skor rata-rata Tes Akhir, Tes Awaldan $N$-gain tes kemampuan pemecahan masalah antara kelas eksperimen dan kelas kontrol.

Berdasarkan data Gambar 1, dapat dilihat bahwa peningkatan kemampuan pemecahan masalah siswa untuk kelas eksperimen berada pada kategori sedang dan untuk kelas kontrol berada pada kategori rendah. Jika ditinjau secara kuantitatif untuk kelas eksperimen yang diberikan perlakuan mengalami peningkatan yang lebih unggul dari kelas kontrol dengan nilai rata-rata $N$-Gain sebesar 46,94\% sedangkan untuk kelas kontrol sebesar 22,34\%.

Cakupan materi yang akan diajarkan yaitu materi suhu dan kalor pada sub bab: 1 . Suhu dan pemuaian; 2. Kalor dan perubahannya, asas black; 3. Perpindahan kalor.

Pada awal penelitian kedua kelas terlebih dahulu diberikan tes awal yang digunakan untuk mengetahui pengetahuan awal siswa sebelum diberi perlakuan. Sedangkan tes akhir diberikan untuk mengetahui kemampuan akhir siswa di kedua kelas dan sebagai data analisis penelitian, yang selanjutnya digunakan sebagai pembanding untuk melihat ada tidaknya 
pengaruh perlakuan yang diberikan pada salah satu kelas yang menjadi sampel penelitian. Setelah kedua kelas diberi perlakuan, selanjutnya kedua kelas tersebut diberikan tes akhir untuk melihat pengaruh pembelajaran yang diterapkan di kelas eksperimen. Tes kemampuan pemecahan masalah siswa pada tes akhir sama dengan pada tes awal yang terdiri dari 5 soal essai.

Bedasarkan hasil analisis jawaban siswa pada setiap sub materi untuk tes akhir di kelas eksperimen dan kelas kontrol, terlihat bahwa kemampuan pemecahan masalah fisika untuk kelas eksperimen lebih baik dibandingkan dengan kelas kontrol. Ini dapat dilihat dari jumlah skor tiap butir soal pada kelas eksperimen yang lebih tinggi daripada kelas kontrol. Berikut analisis jawaban siswa kelas eksperimen dan kelas kontrol, dari 5 nomor soal tes awal kemampuan pemecahan masalah yang telah diberikan.

Jawaban siswa pada soal nomor 1 yakni soal pemecahan masalah tentang pengkonversian skala termometer, pada kelas eksperimen hampir sebagian besar siswa menjawab dengan jawaban yang benar dan cara kerja yang tepat, dari jawaban siswa terlihat mereka memahami cara memformulasikan persamaan sedangkan pada kelas kontrol masih banyak siswa yang menjawab dengan jawaban yang masih keliru, dari jawaban siswa terlihat mereka masih sulit menentukan antara titik didih dan titik beku termometer, sehingga banyak siswa yang keliru dalam mensubtitusikan data yang diketahui. Hal ini dapat dilihat dari jumlah analisis tes pemecahan masalah untuk soal nomor 1 , pada kelas eksperimen sebesar 53 dan kelas kontrol sebesar 42 .

Jawaban siswa pada soal nomor 2 yakni soal pemecahan masalah tentang penerapan asas black, pada kelas eksperimen sebagian besar siswa menjawab dengan jawaban yang benar dan penjelasan yang tepat, hal ini terlihat dari jawaban siswa yang memberikan penjelasan pada setiap tahap permasalahan dari soal sesuai dengan penjelasan ilmiah. Sementara untuk kelas kontrol siswa sebagian besar dapat menjawab setiap tahap permasalahan dari soal, namun penjelasan yang diberikan kebanyakan melenceng dari penjelasan secara ilmiah. Perbedaan dapat dilihat pada selisih dari jumlah analisis tes pemecahan masalah untuk soal nomor 2, pada kelas eksperimen sebesar 54 dan kelas kontrol sebesar 29, dimana selisihnya sebesar 25 skor.

Jawaban siswa pada soal nomor 3 yakni soal pemecahan masalah tentang perubahan wujud zat, pada kelas eksperimen dan kelas kontrol sebagian besar siswa menjawab dengan jawaban yang benar dan penjelasan yang tepat. Dari jawaban siswa terlihat mereka memahami bahwa pengembunan yang terjadi di dalam mobil disebabkan karena perbedaan suhu antara suhu di dalam mobil dan di luar mobil. Yang menyebabkan jumlah analisis soal dikelas eksperimen lebih tinggi daripada di kelas kontrol dikarenakan pada kelas kontrol siswa tidak menjawab sesuai dengan penjelasan ilmiah untuk bagian solusi dari permasalahan pada soal. Mereka sebagian menjawab untuk menghilangkan embun dalam mobil harus menghidupkan alat pembersih kaca mobil. Sementara di kelas eksperimen menjawab dengan cara menyalakan AC agar suhu didalam mobil sama dengan suhu di luar mobil. Perbedaan dapat dilihat dari jumlah analisis tes pemecahan masalah untuk soal nomor 3, pada kelas eksperimen sebesar 49 dan kelas kontrol sebesar 36 .

Jawaban siswa pada soal nomor 4 yakni soal pemecahan masalah tentang kalor, pada kelas eksperimen hanya 2 orang siswa yang menjawab benar dari permasalahan di soal, selebihnya siswa sebagian besar menjawab tetapi tidak memberikan penjelasan. Sementara pada kelas kontrol tidak ada siswa yang menjawab benar dan penjelasan benar. Kebanyakan siswa menjawab tidak sesuai dengan konsep ilmiah, dan adapula yang tidak memberikan penjelasan. Hal ini bisa dilihat pada jumlah analisis tes pemecahan masalah untuk soal nomor 4 pada kelas eksperimen sebesar 48 dan kelas kontrol sebesar 39.

Jawaban siswa pada soal nomor 5 yakni soal pemecahan masalah tentang perpindahan kalor, pada kelas eksperimen dan kelas kontrol hanya sebagian siswa yang hampir menjawab benar, selebihnya siswa kebanyakan menjawab tidak sesuai konsep ilmiah dan menjawab tanpa memberikan penjelasan, bahkan ada beberapa siswa di kelas kontrol yang tidak menjawab soal tersebut. Ketidaksempurnaan jawaban siswa ini dikarenakan banyak siswa yang kehabisan waktu akibat terfokus menjawab soal nomor 1-4, sehingga soal nomor 5 terabaikan dan di sisa waktu terakhir mereka menjawab apa yang terlintas dipikiran mereka. Hal ini bisa dilihat pada jumlah analisis tes pemecahan masalah untuk butir soal nomor 5 pada kelas eksperimen sebesar 49 dan kelas kontrol sebesar 30.

\section{B. Pembahasan}

Berdasarkan hasil analisis jawaban siswa diatas, dapat diketahui bahwa dengan memberikan perlakuan yang berbeda pada kelas eksperimen dan kelas kontrol, akan 
memperoleh kemampuan pemecahan masalah yang berbeda. Pemecahan masalah siswa pada kelas eksperimen relatif sama dengan kelas kontrol pada saat tes awal. Sebelum kelas eksperimen diberi perlakuan, para siswa memberikan jawaban yang kurang tepat dan tanpa alasan yang ilmiah. Setelah diberi perlakuan, sebagian besar siswa mampu menjawab soal dengan tepat dan dengan alasan yang ilmiah. Sedangkan pada kelas kontrol, hanya sebagian siswa yang dapat menjawab soal dengan tepat. Berbedanya hasil jawaban siswa di kelas eksperimen dan kelas kontrol, menandakan bahwa kemampuan pemecahan masalah fisika siswa dikelas eksperimen lebih baik daripada di kelas kontrol. Dimana pada kelas eksperimen diberikan perlakuan model pembelajaran kooperatif dengan pendekatan saintifik menggunakan strategi TAPPS, sedangkan pada kelas kontrol menggunakan model pembelajaran yang diterapkan di sekolah, yaitu model Problem Based Learning.

Proses pembelajaran yang diterapkan pada kelas eksperimen mempunyai 6 fase, yaitu Fase 1: Menyampaikan tujuan dan mempersiapkan siswa, Fase 2: Menyampaikan informasi, Fase 3: grouping, Fase 4: Kerja kelompok, Fase 5: Mengevaluasi dan penilaian, Fase 6: Memberikan pengakuan atau penghargaan. Kemudian dari 6 fase tersebut, pendekatan saintifik diterapkan pada fase ke 4 yaitu kerja kelompok, dimana pada saat siswa melakukan pekerjaan kelompok siswa dituntut untuk mengamati, menanya, mengumpulkan informasi, mengolah informasi, dan mengkomunikasikan. Pada saat pembentukan kelompok, siswa dibagi kedalam beberapa kelompok yang tiap kelompoknya terdiri dari dua orang siswa, dan masing-masing siswa dalam kelompok tersebut memiliki peran sebagai problem solver dan listener. Problem solver bertugas untuk mengetahui permasalahan yang diberikan dan menyelesaikan permasalahan tersebut. Listener bertugas menuntun problem solver untuk terus berbicara dalam menyelesaikan permasalahannya. Kemudian bertukar peran untuk menyelesaikan permasalahan kedua. Sedangkan proses pembelajaran yang diterapkan di kelas kontrol menggunakan model pembelajaran Problem Based Learning yang terdiri dari 5 fase, diantaranya: 1. Mengoreintasi peserta didik pada masalah. 2. Mengorganisasikan kegiatan pembelajaran, 3. Membantu investigasi mandiri/kelompok, 4. Mengembangkan dan menyajikan hasil karya, 5. Analisis dan evaluasi proses pemecahan masalah. Pada proses pembelajaran, siswa dibagi dalam kelompok kecil dengan anggota kelompok terdiri atas 4-5 orang.

Selama kegiatan diskusi berlangsung guru memantau jalannya diskusi, memberikan bimbingan serta motivasi agar siswa aktif terlibat dalam kegiatan pemecahan masalah di kelompok masing-masing. Guru memberikan motivasi agar siswa aktif berdiskusi karena hasil pemikiran beberapa siswa akan lebih baik daripada hasil pemikiran satu siswa saja [7]. Aktivitas guru dan siswa pada kelas eksperimen lebih tinggi daripada kelas kontrol. Ini berarti bahwa siswa lebih aktif ketika pembelajaran dengan pendekatan saintifik menggunakan strategi TAPPS.

Berdasarkan pengujian hipotesis tes akhir satu pihak dengan taraf signifikan $(\alpha=0,05)$ diperoleh thitung sebesar 3,15 dan tabel sebesar 1,68 . Hal ini menunjukkan bahwa thitung $>t_{\text {tabel }}$ yang artinya hipotesis nol $\left(\mathrm{H}_{0}\right)$ ditolak sedangkan hipotesis $\mathrm{H}_{1}$ diterima sehingga dapat disimpulkan bahwa terdapat pengaruh setelah diterapkannya pembelajaran dengan pendekatan saintifik menggunakan strategi TAPPS untuk meningkatkan kemampuan pemecahan masalah fisika siswa.

Penelitian ini didukung oleh penelitian yang dilakukan oleh [8] menyatakan bahwa pengaruh strategi pembelajaran thinking aloud pair problem solving (TAPPS) berdasarkan hasil penelitian dan analisis data menunjukkan bahwa tingkat kemampuan pemecahan masalah siswa mengalami peningkatan. Selain itu, menurut penilitian [9] menunjukkan bahwa penerapan model pembelajaran thinking aloud pair problem solving (TAPPS) dapat meningkatkan hasil belajar fisika siswa.

Penelitian ini menyajikan hal yang baru dari kedua rujukan penelitian di atas, yaitu pada bagian strategi pemecahan masalah yang akan di terapkan. Dimana strategi pemecahan masalah yang digunakan tersebut adalah visualisasi masalah, mendeksripsikan masalah dalam istilah-istilah fisika, merencanakan solusi, menyelesaikan rencana solusi,mengecek dan menguji solusi.

\section{KESIMPULAN DAN SARAN}

\section{A. Kesimpulan}

Berdasarkan hasil penelitian dan analisis data yang diperoleh, maka dapat disimpulkan bahwa terdapat pengaruh pendekatan saintifik menggunakan strategi Thinking Aloud Pair Problem Solving (TAPPS) untuk meningkatkan kemampuan pemecahan masalah fisika siswa di kelas X SMA Negeri 8 Palu. Berdasarkan dari hasil pengujian hipotesis tes, dengan taraf signifikan $\alpha=0,05$ diperoleh thitung $>$ tabel atau 
3,15 > 1,68 atau $\mathrm{H}_{0}$ ditolak dan $\mathrm{H}_{1}$ diterima, yang berarti terdapat pengaruh pembelajaran dengan pendekatan saintifik menggunakan strategi Thinking Aloud Pair Problem Solving (TAPPS) untuk meningkatkan kemampuan pemecahan masalah fisika siswa.

\section{B. Saran}

Berdasarkan temuan-temuan selama penelitian, penulis mengajukan beberapa saran sebagai perbaikan dimasa mendatang yaitu sebagai berikut :

1) Pada penelitian ini pembelajaran dengan pendekatan saintifik menggunakan strategi Thinking Aloud Pair Problem Solving (TAPPS) terbatas pada materi suhu dan kalor. Penelitian dapat dilanjutkan dengan menggunakan model yang sama pada pokok bahasan lainnya, untuk mendapatkan masukan yang lebih lengkap agar pengaruh pembelajaran dengan pendekatan ini jelas teramati.

2) Untuk menerapkan pembelajaran dengan pendekatan saintifik menggunakan strategi Thinking Aloud Pair Problem Solving (TAPPS) sebaiknya langkah-langkah yang digunakan lebih terarah, sehingga guru pada prinsipnya hanya berperan sebagai fasilitator.

3) Dalam merancang rencana pelaksanaan pembelajaran dengan pendekatan saintifik menggunakan strategi Thinking Aloud Pair Problem Solving (TAPPS), diperlukan pengaturan kesesuaian dengan waktu yang tersedia di lapangan.
p-ISSN 2338-3240, e-ISSN 2580-5924

4) Untuk peneliti selanjutnya dapat menerapkan pembelajaran dengan pendekatan saintifik menggunakan strategi Thinking Aloud Pair Problem Solving (TAPPS) menggunakan metode-metode yang lebih inofatif.

\section{DAFTAR PUSTAKA}

[1]. Rahmat, dkk. "Kemampuan Pemecahan Masalah Melalui Strategi Pembelajaran Thinking Aloud Pair Problem Solving Siswa Kelas X SMA". E-Journal Program Pascasarjana Universitas Negeri Malang. Vol. 18, 2014.

[2]. Jaedun. dkk. "Problem Solving dalam Pembelajaran Fisika untuk Meningkatkan Kemampuan Mahasiswa Berpikir Analitis". Jurnal Kependidikan, vol. 3, pp 1416, 2010.

[3]. Undang-Undang Republik Indonesia Nomor 20 Tahun 2003 Tentang Sistem Pendidikan Nasional.

[4]. Hamruni. Strategi Pembelajran. Yogyakarta: Insan Madani, 2012.

[5]. Heller et al. "Teaching problem solving trough cooperative grouping. Part 1: Group versus individual problem solving". American Journal of Physics, vol. 60, no. 7, 1992.

[6]. Sugiyono. Statistika untuk Penelitian. Bandung: Alfabeta, 2015

[7]. L. Anita. Cooperative Learning: Mempraktikkan Cooperative Learning di Ruang-Ruang Kelas. Jakarta: Gramedia, 2008.

[8]. R. Muhardito dan S. Zulaikah. "Kemampuan Pemecahan Masalah Melalui Strategi Pembelajaran Thinking Aloud Pair Problem Solving Siswa Kelas X SMA". E-Journal Program Pascasarjana Universitas Negeri Malang, vol. 18, 2014.

[9]. Ratnasari, M. Ali dan N. Dewi. "Penerapan Model Pembelajaran Thinking Aloud Pair Problem Solving (TAPPS) untuk Meningkatkan HasilBelajar Fisika Siswa". Jurnal Pendidikan Fisika Tadulako (JPFT), Vol. 2 No. 1, 2014. 